6-30-2015

\title{
Labour Law and Transnational Law: The Fate of Legal Fields / The Trajectory of Legal Scholarship
}

Harry Arthurs

Osgoode Hall Law School of York University, harthurs@osgoode.yorku.ca

Follow this and additional works at: http://digitalcommons.osgoode.yorku.ca/conference_papers Part of the Labor and Employment Law Commons

\section{Recommended Citation}

Arthurs, Harry, "Labour Law and Transnational Law: The Fate of Legal Fields / The Trajectory of Legal Scholarship" (2015). Conference Papers. 2.

http://digitalcommons.osgoode.yorku.ca/conference_papers/2 


\title{
LABOUR LAW AND TRANSNATIONAL LAW: \\ THE FATE OF LEGAL FIELDS / THE TRAJECTORY OF LEGAL SCHOLARSHIP
}

\author{
Harry Arthurs \\ York University, Toronto \\ Dickson Poon Institute of Transnational Law \\ Kings College London \\ June 30, 2015
}

In this lecture, I'm going to explain how and why I came to write my article, The Law of Economic Subordination and Resistance. ${ }^{1}$ I hope that by doing so, I will be able to shed some light not only on my own field of labour law, but on the larger problem of how legal fields or domains of legal knowledge, come into existence, change or become obsolete, and in the end are either transformed or superseded altogether. I will be talking about labour law, but I hope you will be thinking about transnational law. I'm going to try to persuade you that the invention and transformation of these two fields have something in common. But I'm going to go further. I hope to convince you that their ultimate fate is determined by some of the very same forces. Transnational law, I am going to argue, can only survive if it learns from the short, sad history of labour law.

So to begin at the beginning: I am a labour lawyer. For much of my early career, I tried conscientiously not only to show how the present law fails to produce logical, just and workable outcomes, but also to propose new legal arrangements that would be in everyone's interests. Most of my colleagues were doing the same thing, though of course we didn't always agree on either our critique or our proposals for reform. But we had some good ideas, we tried hard to persuade people to adopt them, and sometimes we even succeeded. But gradually it became obvious that even our best ideas, even ideas that judges and legislators adopted and translated into law, did not necessarily make the world a better place for workers. Nor did the adoption of new international and constitutional protections for workers. Nor did the election to office of labourfriendly political parties. 
Admittedly, I may have been a slow learner. It took me some time. However, in the end, I came to accept that law lacks the capacity to fundamentally alter power relations. Those relations are ultimately determined not by law but by political economy, and they are found not in the law reports or statute books but embedded in cultural practices and social structures. No "silver bullet" with "law" written on it, I came to feel, would fundamentally alter labour markets or relations of employment. Law's contribution would be very much at the margins. Workers would only get the rights they were prepared to struggle for.

Well, they struggled — and they lost. The labour movement is almost everywhere in retreat. Union membership, power and influence are all declining rapidly - in some countries, they are near the vanishing point. Labour and social democratic parties are able to remain "credible" only if they abandon their historic values, alliances and programs. The welfare state has been fatally weakened by forty years of ascendant neo-liberalism, and more recently by the force majeure of austerity. Labour market institutions and regulatory agencies are in disarray — often understaffed and disempowered. Workers' share of GDP is diminishing; wages have lagged inflation; some combination of precarious employment, underemployment and unemployment afflicts almost all advanced economies. The result, as we all know, is that these economies are growing more and more unequal, and the problems of economic subordination are growing more severe.

How can we explain these developments? Globalization, technology and market fundamentalism are the most obvious causes. However, one more cause occurred to me, which I explored in an essay entitled Labour Law after Labour?2 I suggested that labour is no more. It is no longer a sociological descriptor: workers now tend to selfidentify as members of the middle class rather than the working class, as consumers rather than producers; they mobilize politically around issues of race, religion, national identity or lifestyle, not the defence of their class interests; and working class culture has been absorbed into a commercialized, popular culture. Worse yet, labour is no longer a matter of urgent public concern. So far as I know, hardly any newspaper in the United Kingdom or North America has a labour specialist. In many jurisdictions, 
labour is no longer a free-standing field of public policy: many governments have assigned the functions of their labour departments to ministries of welfare or economics; decisions made by Finance and Trade and Industry departments turn out to be far more consequential for workers' wellbeing than anything that happens in whatever ministry now has formal responsibility for employment standards or collective bargaining. And to my great distress, Labour is no longer a popular academic subject: in business schools, courses in labour or industrial relations have given way to courses in human resource management; in many law schools, labour law is either not taught, taught by practitioners rather than tenured scholars, or disaggregated into specialist regulatory fields such as pension law or discrimination law.

And now a question it pains me to ask: What is the future for a legal field called labour law in which the law is designed to protect people who no longer think of themselves as "labour" and in which the very concept of "labour" is disappearing from public, political and academic discourse? And the answer pains me even more: it is not a bright future.

I will return to this theme, the theme of my article Labour Law after Labour, in a moment. But first I want to point to two great anomalies in the present situation. First, the disappearance of labour and the decline of labour law's importance coincide with a period during which, in many advanced economies, labour has acquired more formal legal rights than it ever enjoyed before. In my own country, Canada, for example, the courts have decided that labour's rights to organize, to bargain collectively and to strike and picket are all protected by the constitution. And parallel developments have taken place in the space governed by transnational law where the regulation of labour rights has expanded enormously. Now the second anomaly: during this same period, while labour's social, economic and political influence have been deteriorating, labour law scholarship has been flourishing. It has become more theoretically and methodologically sophisticated and diverse; it has begun to address law at every level from the indigenous law of the workplace to national systems of labour market regulation to the domain of transnational labour and social rights; and it has belatedly begun to explore the problems of previously neglected worker cohorts such as migrant workers, domestic workers and those engaged in non-waged work. Perhaps these two 
anomalies lend credibility to my thesis that struggle, not law, ultimately defines the rights that workers actually enjoy.

In any event, I am sure you will understand why I have been feeling recently that my intellectual life's savings, almost entirely invested in labour law, are very much at risk. "How did this happen?", I asked myself. "Am I the victim of historical trends, rather than poor personal judgment?" In order to answer this question, I decided to revisit the history of labour law: when and why did it emerge, when and why did it flourish, when and why did it decline? Some answers to these questions are found in The Law of Economic Subordination and Resistance. I will summarize them very quickly.

Labour law began as an academic discipline and field of professional legal practice in the 1920 s - a response to the social upheavals of the late $19^{\text {th }}$ century, to the Great War and the Russian Revolution and to widespread outbreaks of proletarian discontent. It took on special urgency during the Great Depression of the 1930s, and really came into its own during the period between 1945 and 1960 when unions gained power and legitimacy as part of what is known as the postwar settlement. By about 1960, even conservative law faculties, law publishers and lawyers' organizations were prepared to acknowledge labour law as a legitimate field of legal learning and practice. However, in the 1970s, the postwar settlement began to unravel. Over the next four decades, as I have mentioned, globalization, technology, market fundamentalism and the disappearance of working class identity and solidarity have combined to launch unions on a long-term downward trajectory from which they may never recover. With the decline in unions has come a decline in labour's political and economic power, and that decline in turn has undermined labour law. After all, who is interested in advocating, designing, administering, studying or practising a field of law whose output is likely to be frustration and disappointment?

So, labour law has had a fairly short life, in historical terms, as well as a mostly unhappy one. But wait! Could things have turned out differently? Better for workers? Better for society? Better for labour lawyers like me? This is the point in my article at which I introduce my thought experiment, my historical counter-factual. A counter-factual is something that might plausibly have happened, but didn't. Suppose, I conjecture, that 
instead of inventing a legal regime that had only to do with labour, we had created something more ambitious - a field of law that was concerned not just with employment but with all forms of economic subordination. As I point out, conceivably this might have happened during the 1930s, when a wide variety of people - workers, small businesses, farmers, consumers, investors - were all recognized to be suffering as a result of a crisis of unregulated capitalism and inept governance. America came close to responding to their plight by adopting the NIRA, the National Industrial Recovery Act of 1935 -one version of my law of economic subordination and resistance. Other countries, including Canada, might have followed if the American experiment had succeeded. But the NIRA was struck down by the U.S. Supreme Court; some parts of it were reintroduced in piecemeal fashion, including what came to be known as the National Labor Relations Act; and the Great Depression gave way to preparations for war, the war itself and postwar reconstruction. My counterfactual never happened.

But could it happen today? Is the crisis of capitalism comparable to that of the 1930s? And might a new legal field called "the law of economic subordination and resistance" have something to contribute to the resolution of that crisis? Let's pursue those questions and see where they take us.

The last question first. In my article I stress the conceptual incoherence of labour law, which consists in most common law countries of bits and pieces of private and public law, of general law and special statutes, which express very different value assumptions, and use different conceptual vocabularies, but which are deemed to be core elements of labour law because they happen to address the same phenomenon: the employment relation. But if that is the criterion for inclusion in the domain of labour law, why not many other things that seldom find their way onto the labour law curriculum or the dockets of labour law practitioners: why not trade law and immigration law that significantly influence the balance of power in the labour market? Why not tax or corporate law that establish the dynamic of business decisions that in turn lead to the hiring or firing of thousands of workers? Why not the laws that govern technical training and retirement security, social housing and health care, that at one remove but with 
great power, help to determine what social goods will be provided by the employer, what by the state and what by workers themselves?

So, labour law is incoherent. Would the law of economic subordination and resistance be any less so? The unifying theme of my counterfactual is that gross disparities of economic power are inherent in capitalism, and that certain generic legal technologies can and should be used to reduce those disparities or to mitigate their harmful effects. The aggregation of countervailing power is one such technology; the requirement that all economic bargains should be fair and transparent is another; state imposition of minimum or standard terms is another; the displacement of private market provision of social goods by public provision is another; and the list goes on. My suggestion, then, is that experts in the technologies of resistance might be able to show tenant groups what they can learn from labour unions, to show the owners of small business franchises what they can learn from farmers, and to show mortgagors what they can learn from consumers. The end point of the exercise is by no means revolutionary. It is merely to save capitalism from its own excesses, which are very much in evidence today.

If pressed, I would have to admit that the law of economic subordination and resistance is likely to be no more coherent than labour law. Indeed, by ignoring the very different social and economic contexts in which subordination and resistance occur, it might turn out to be even less coherent. Nonetheless, it has both conceptual and practical attractions.

Conceptual attractions first: The likely incoherence of my imagined law of economic subordination and resistance is not a mere oversight on my part, an accidental failure to integrate diverse legal and regulatory systems. Rather, it is deliberately constructed as the mirror image of our present incoherent legal system which has been unable to perceive - let alone link, analyze or respond to - many important realworld social, economic and political developments. Although these developments are clearly related in both their origins and their consequences, they are currently assigned to separate intellectual domains on the basis of a system of legal and regulatory taxonomy constructed at another moment in history, and with a different set of value assumptions. Thus, the problems of consumers are characterized as "contract law", of 
tenants as "property law", of debtors as "insolvency law", and of workers as "labour law" or "employment law". Similarly, the decision-making processes by which their fate is determined are variously assigned to the domains of "constitutional law" or "administrative law", "corporations" or "securities law".

However, such labels fail to capture the underlying structural pathologies of contemporary capitalism whose manifestations they represent. By contrast, descriptors such as those I have proposed - "subordination" and "resistance" - or others such as "precarity" or "exclusion", call our attention to what these problems have in common: they all arise from decades of domestic and transnational market fetishism. Admittedly, my alternative descriptors - subordination and resistance, precarity and exclusion - are provocative: but no more so than the terms that have been deployed to ease us gradually into the post-affluent, post-social democratic era that is our "new normal". I have in mind such reassuring terminology as "smart" or "responsive" regulation, "best practices" and "new public management" which are designed to make us feel good about deregulation and the retreat of the state from its responsibilities to protect citizens from malfunctioning markets and malevolent corporations. Or I might mention "flexibilisation", "responsibilisation" and "contractualisation". Such terms are used to make it appear that recent labour market and welfare "reforms" are not only inevitable but logical and desirable. Who could possibly be against flexibility, against responsibility, against freely made contracts? Who indeed - except those who experience declining living standards and the resulting degradation of their civic and cultural life. My point, in short, is that conceptual language can render visible or invisible, controversial or conventional, the developments they purport to describe.

There is also, despite its incoherence, a distinctly practical dimension to a legal field that answer to the name of the law of economic subordination and resistance. First, it would be a response to the argument that labour law is nothing more than an attempt to claim for workers privileges that are unavailable to other groups in society. Why, for example, should workers enjoy access to special tribunals with expedited procedures and enhanced remedial powers, when consumer and tenancy disputes must be dealt with through the slow, clumsy, expensive and often ineffective procedures of the regular 
courts? The answer to such questions is the core notion of the law of economic subordination and resistance: all subordinate people should enjoy access to similar means of resistance. Second - a related point - if other groups such as farmers and small businesses could realistically aspire to the social gains won by workers in the heyday of collective bargaining and the welfare state, might they not be less hostile to unions than they now are? And third - perhaps too much to hope for - might not a broad coalition of social forces emerge from the shared sense of workers and other subordinate groups that they have a common interest in finding ways to resist their subordination, or at least to strike a better balance between their interests and those of powerful corporations?

That's how legal fields emerge, take hold or decline. Which brings me finally to the business of this Summer Institute. I'll try to explain what transnational law has to do with labour law other than it being another legal field in transition.

One connection is that both fields have been influenced by legal pluralism - by the notion that the state has no monopoly on the making of law or its implementation. I developed this notion in Labour Law Without the State, ${ }^{3}$ one of my first attempts to describe transnational labour law. In that article, I pointed out that labour law had never been state-centred; it had always included an important element of informal and indigenous law making. But as I had to acknowledge in a later article, Landscape and Memory, ${ }^{4}$ although labour law was an example of legal pluralism, it was nonetheless shaped by political economy which profoundly influences power relations in labour markets and workplaces, as it does in so many other contexts.

My next attempt to describe transnational labour law was in a piece called Extraterritoriality by Other Means. ${ }^{5}$ Here I focussed on the practical mechanisms by which globalization constructs its own normative systems. My sub-title - How Labor Law Sneaks Across Borders, Conquers Minds and Controls Workplaces Abroadpretty much tells the story. And finally, in a recent piece - Making Bricks Without Straw: The Creation of a Transnational Labour Regime 6 - I try to bring together the various lines of my work. Is it possible, I ask, that my counter-factual thought experiment 
— the law of economic subordination and resistance - might help us to think of new ways to protect workers' interests in the context of globalization?

Globalization has played a leading role in the destruction not only of national labour law systems but also of other regimes whose ambition is to restore a measure of fairness to relations characterized by severe inequalities of economic power. We must therefore learn how to achieve social justice in the workplaces of what looks like being a permanently globalized world. However, we have been handicapped in pursuing this project by the absence of a big idea, of a plausible alternative vision of economic relations. Perhaps, I speculated, maintaining our traditional focus on labour has contributed to this difficulty. Labour lawyers generally insist that their subject is a unique, a distinct, legal field. They often make their point by reminding us of the moral implications of the fact that "labour is not a commodity". However, as I point out in Bricks without Straw, this justification for labour law "[valorizes] class membership or the employment relation" - both of which are concepts with a diminishing grip on reality. Fortunately, there is another way of looking at labour law. As I suggest:

The ... narrative ... of employment can be understood as a specific instance of injustice that reinforces the case for adherence to a general principle: everyone is entitled to freedom, dignity and a decent life; everyone should be treated with fairness and compassion. The ultimate value ... is social justice, not identity....

In effect, I was offering a new ethical justification for the new legal field that I was proposing, a field built around all relations of economic subordination and all technologies of resistance.

Coincidentally, this formulation also opened up a new possibility to expand the spatial reach of labour law. Today most markets operate across national boundaries and require some form of transnational regulation. However, while a framework of transnational law is emerging to regulate capital and commercial markets, the regulation of labour markets has lagged badly. Worse yet, the absence of effective universal labour standards has enabled regulatory competition amongst states that are willing to attract investors by ensuring the subordination of their own workers. If workers' rights and interests were to be inscribed along with those of other subordinate groups on a comprehensive agenda of developmental and trade concerns - rather than as a 
separate and unique project called "labour law" - they might gain the same international visibility and transnational support that attaches to, say, environmental or health or consumer protection issues.

To do this, or course, requires a robust response to the discourse of global "thought leaders" who seek to "normalize" existing relations of subordination by demonstrating that they are not only inevitable but morally defensible. I propose two related examples. According to orthodox economists, Greek pensioners deserve to suffer significant reductions in their standard of living because they have tolerated a political system characterized by corruption, tax evasion, and financial irresponsibility. Likewise, Canadian workers deserve to see their jobs shipped to Mexico or China because collective bargaining and the tax burdens of the welfare state have led to unsustainably high labour costs in the manufacturing sector. In this fashion, the discourses of market fundamentalism and global neo-liberalism legitimate a system of transnational governance in which the interests of subaltern groups - both labour and non-labour receive little attention and less sympathy. Collective challenges to this way of thinking are a necessary first step towards alternative models of capitalism and of global governance.

Which brings me - at last - to the prospects of transnational law as an instrument for social justice. Let us assume, as the literature suggests, that there already exists in embryo a body of transnational law governing labour and social rights, human rights more generally and even, as Boa Santos proposes, a jus humanitatis. Let us suppose as well, contrary to the facts, that the widely-recognized regime of lex mercatoria has begun to incorporate principles that ensure basic fairness for the subordinate party in contractual dealings to- debtors, consumers, franchisees and so on. Let us imagine, in other words, that my counterfactual was instead factual, and that the law of economic subordination and resistance has already emerged in the interstices of transnational law. What would that mean?

I have to be careful here. It would not mean nothing. In given circumstances this new body of law could be used to embarrass corporate wrongdoers, educate public opinion, and elicit remedial action from governments that now and again want to do the right 
thing. But that's the problem. Unfortunately the history of labour law tells us under what "given circumstances" this new branch of law would likely be effective. When labour lost its power, labour law became a lost cause; and until other economically subordinate communities regain the power that labour has lost, my thought experiment will not succeed. There will never be a transnational law of economic subordination and resistance, to speak plainly, unless and until social movements have the power to do economic harm to corporations and political harm to governments. International conventions and covenants, universally recognized social rights, corporate best practices and codes of conduct, principles of contract and soft law regimes: none of these will matter much unless people who do not now have power are somehow able to mobilize effectively and on a broad front.

This will not be easy. The labour movement is clearly disempowered; most other subordinate groups are unwilling to mobilize or, if they do, to stay mobilized for a sustained period of time. Further, many such groups mistrust each other; and that mistrust prevents the formation of broad coalitions. And finally, the complexity of global markets largely hides corporations and governments from scrutiny and shields them from pressure. In short, the same circumstances that have led to existing imbalances of wealth and power across the global economy and in national economies, are also preventing the emergence of new legal technologies of resistance.

I admit, then, that prospects for rescuing my intellectual investment through a turn to transnational law seem poor. Why then should we bother with thought experiments like the law of economic subordination and resistance? Why should we trouble ourselves about the emergence or non-emergence of a regime of transnational law? One strong proponent of transnational law answers these questions in the following way. The conceptualization of transnational law as a new legal field (he says)

... might help both juristic practice and socio-legal scholarship by making it possible to organize, link and compare what often appear as very disparate and problematic, but increasingly significant, types of regulation. 
The same might be said for the law of economic subordination and resistance. And then he makes an even more important claim:

The attempt to clarify the nature of transnational law ... forces a fundamental reconsideration of relationships between the public and the private, between law and state, and between different sources of law and legal authority. ${ }^{7}$

I agree with those claims, and I will add another, yet more compelling, reason why we should do thought experiments. Their great virtue is that they remind us of the tenuous connection between legal representations of social relations, and their reality. Concern, even outrage, about that divergence, I should add, is what has caused the current explosion of excellent labour law scholarship, as many scholars suggest ways to rescue, revise or replace existing, obsolete or failed approaches to the field. But alas, much of that scholarship (mine not least) is unlikely to produce practical real-world consequences.

Will transnational law suffer the same fate as labour law? Will it come to be regarded as another thought experiment that was intellectually provocative, but did not achieve its ambitious objectives of bringing the rule of law and the regime of justice to a globalized world?

As you will perhaps conclude from your own research and the discussions this week, the definition of transnational law is contested. For some scholars, it includes all of the normative regimes that govern relationships or transactions across state boundaries, including but not limited to those that emanate from state law or from agencies empowered by treaties or conventions entered into by states. For others, transnational law is a pluralistic legal system, constructed from the bottom up, by transnational actors including corporations, sectoral business associations, technical bodies, financial institutions, agencies for dispute settlement, social movements, trade unions and communities. ${ }^{8}$ For others still, transnational law offers, above all, a critical perspective on the role of legal regulation in a world that is deeply divided economically and politically. Whatever the definition, one thing is clear: conventional descriptions of law that begin and end with the state are no longer accurate, if they ever were; in our search 
for greater accuracy we must somehow take account of the multiple normative systems that now govern the transnational movement of goods, capital, people, culture, technique, information and ideas. I am going to refer to those systems as "transnational law" without worrying too much about what is included and what is not in order to make my final point.

It is this: We can admire the ingenuity and the energy of those who have built transnational law, whether they set out to do so or not; we can admire the intellectual acuity of those who have noted its existence and theorized about it in such a stimulating fashion. But what we cannot do is to romanticize transnational law. Transnational law is very much like national law, only more so. It shares the strengths of national law, but also its weaknesses. It is often inaccessible to those who need it most. Like national law, when it is invoked, it is often ineffective. Like national law, it reflects and frequently reinforces existing power relations but is far less often successful in revising them.

How then do we establish a just and effective regime of transnational law? Just as we do with national law: by broad-based political and social mobilization, by winning the intellectual and cultural battle for people's hearts and minds, by organizing and demanding and pressuring for reform of the economic order that the law is meant to govern. In other words: by making the law of economic subordination and resistance a global reality. 
$1 \quad$ Labour Law as the Law of Economic Subordination and Resistance: A Thought Experiment (2013) 34 Comparative Labor Law and Policy Journal) 585

$2 \quad$ Labour Law After Labour in Guy Davidov and Brian Langille (eds.) What Is Labour Law For? (Oxford UP, 2010) 13

$3 \quad$ Labour Law without the State? (1996) 46 U. Toronto Law Journal 1

$4 \quad$ "Landscape and Memory": Labour Law, Legal Pluralism and Globalization in T. Wilthagen (ed.) Advancing Theory in Labour Law in a Global Context (North Holland Press, 1997) 21

$5 \quad$ Extraterritoriality by Other Means: How Labor Law Sneaks Across Borders, Conquers Minds and Controls Workplaces Abroad (2010) 21 Stanford Law \& Policy Review 527

$6 \quad$ Making Bricks Without Straw: The Creation of a Transnational Labour Regime in Claire Kirkpatrick, Joanne Scott \& Gráinne de Búrca (eds) Critical Legal Perspectives on Global Governance: Liber Amicorum David M. Trubek (Hart Publishing, 2013) 129

$7 \quad$ Cotterrell, Roger, What Is Transnational Law? (March 13, 2012). Law \& Social Inquiry, Vol. 37, No. 2, 2012; Queen Mary School of Law Legal Studies Research Paper No. 103/2012. Available at SSRN:http://ssrn.com/abstract=2021088

Peer Zumbansen, Transnational Legal Pluralism (2010) 10 Transnational Legal Theory 141 